Voces

\section{Una reflexión sobre la profesión de museólogo}

Ana Carro Rosell

Presidenta de la Asociación Española de Museólogos (AEM)

Es obvio que los museos son expresión de la cultura, instrumentos dinámicos de la educación de la sociedad, que deben ofrecer servicios nuevos y creativos. Esta última exigencia, que hoy en día nadie pone en duda, no siempre ha estado tan clara y estas instituciones hasta hace algunas décadas eran fundamentalmente espacios de conservación y estudio de colecciones, que no prestaban una especial atención al entorno al que se asociaban o debían servir.

Los cambios organizativos dentro de las instituciones museísticas son y están siendo necesarios para dar respuesta a las necesidades que desde diferentes estados se les exige. Esta exigencia sin duda recae sobre las personas que están al frente y trabajando en las instituciones, pero ¿estamos preparados para ello? ¿Estamos dispuestos a aceptar la necesidad de una formación continua? ¿Estamos acostumbrados a que se nos evalúe o incluso a evaluarnos a nosotros mismos? ¿Aceptamos la necesaria interdisciplinariedad de la museología? ¿Necesitamos tener muchos conocimientos de "algo" o pocos de muchas y variadas materias? ¿Queremos, debemos ser dirigidos por el mercado?... Parece que no nos queda mas remedio que aceptar esto, si queremos que la institución museística sea provechosa para la sociedad.

Estamos seguros de que si hiciéramos estas preguntas a muchos profesionales de los museos las respuestas serian muy diferentes e incluso contradictorias porque el perfil del profesional de museo es muy variado en su formación, inquietudes...

En nuestro país no existen estudios de grado en museología y sólo existen estudios de postgrado impartidos desde las universidades que tienen muy poco reconocimiento, con diversidad de titulaciones (experto, máster, diploma de posgrado, diplomado especialista). Casi todos abarcan el patrimonio en general, solamente unos pocos se dedican exclusivamente a la museología y parece que sus programas están en continua revisión.

El panorama de la formación en España existe y evidencia que se ha avanzado en los últimos años de manera que podemos afirmar que tenemos muchas personas con buena formación. La formación en Museología contribuye en gran medida a que la federación de profesionales que intervienen en los museos (conservador, educador, diseñador, relaciones públicas, restaurador, gerente, documentalista, vigilante, técnico de mantenimiento...) conciba el trabajo no como algo fragmentario sino como un conjunto unitario. La actuación de los profesionales dependerá del puesto de trabajo que tengan que desempeñar y, lamentablemente, en muchas ocasiones la actuación del profesional no se corresponde con su formación y viceversa.

Un verdadero profesional tiene que disponer de unos conocimientos y debe actualizar ese saber. Mantener un alto nivel de motivación y creatividad entre los profesionales de los museos es la única forma de ir adaptándose a los continuos y vertiginosos cambios que cada día surgen en las instituciones museisticas.

La Asociación Española de Museólogos desde hace más de 12 años lucha, entre otras cosas, por promover la investigación y los estudios sobre los museos y la museología, difundir los principios de la museología, servir de canal de comunicación ente los profesionales, dentro y fuera de nuestras fronteras, y con especial atención a Iberoamérica y otras comunidades hispano hablantes, por reivindicar la importancia de los museos en el desarrollo de la sociedad en cuanto a la educación, los valores democráticos, la cultura, la economía, la identidad colectiva, la tolerancia, la cohesión social, el equilibrio tradición-modernidad y el uso constructivo del ocio. Somos conscientes de que no podremos conocer la utilidad de todo este trabajo dedicado a intentar mejorar la institución museistica hasta que no pasen varios años.

El problema viene por la necesidad de poner de acuerdo a todos los profesionales que nos dedicamos de una u otra manera a la museología para defender nuestra profesión, evitar el intrusismo y estar preparados para afrontar los retos planteados en cada momento.

Desde la AEM estamos dispuestos a participar en todo lo contribuya a mejorar y reconocer la profesión de museólogo, pero afirmamos que el cambio sólo se puede producir si entre todos nos lo proponemos.

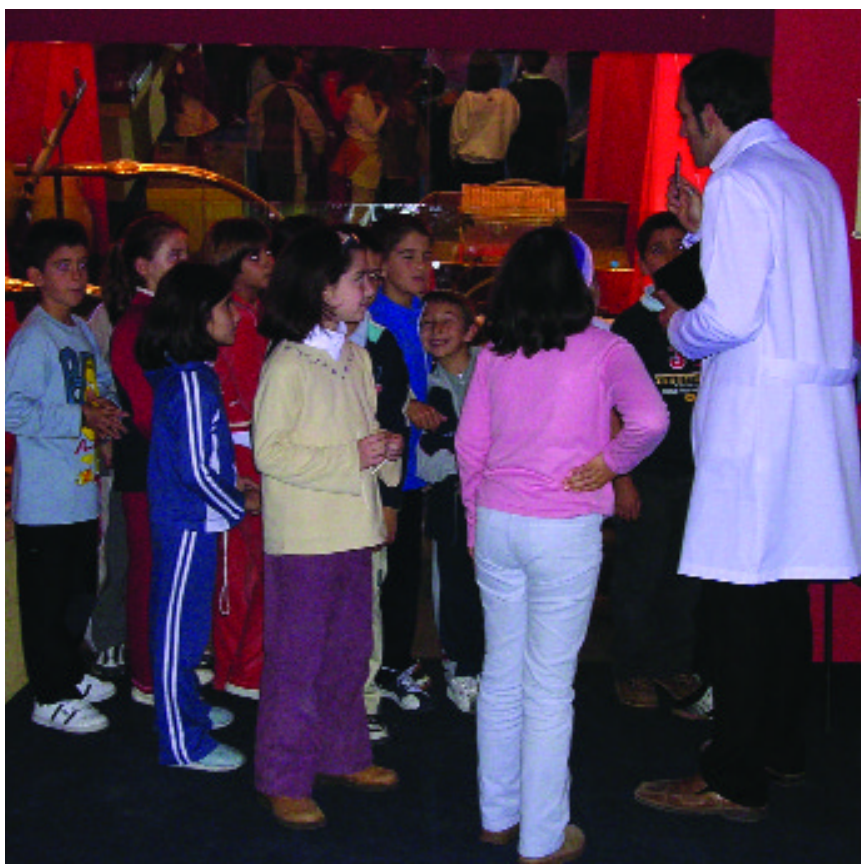

Profesional de la didáctica en museos. Fuente: Espiral, animación del patrimonio (www.espiralpatrimonio.com) 